\title{
Upgrading the language learning and teaching process for Zees
}

\section{Proces uczenia się i nauczenia języka pokolenia Z}

\author{
Anna KULIŃSKA ${ }^{1}$ \\ Ateneum-Szkoła Wyższa w Gdańsku
}

\begin{abstract}
The modern student is surrounded by technology, which results in their both social behaviours and their learning habits. Research indicates that although the attention span of modern reaches much lower levels than with previous generations, their 'bursts' of attention are more frequent and also their connecting and encoding abilities are more efficient. These changes in their cognitive functions should be answered by the adaptation if the teaching process in order to minimise the negative consequences of shorter attention span and maximise their potential.

Keywords: Concentration Span, Generation Z, Digital Environment

Streszczenie

Współczesny uczeń otoczony jest z każdej strony technologią, co ma swoje konsekwencje zarówno $\mathrm{w}$ jego zachowaniach społecznych, jak również $\mathrm{w}$ kształtowaniu się nawyków dotyczących uczenia się. Badanie dowodzą, że choć umiejętność skupiania się współczesnych nastolatków osiąga znacznie niższy poziom niż wcześniej, ich uwaga 'odnawia' się z większą częstotliwością, a jednocześnie cechuje ich umiejętność sprawniejszego przełączania się pomiędzy zadaniami. Takie zmiany w funkcjonowaniu poznawczym wymagają odpowiedniego dostosowania procesu dydaktycznego tak, aby zminimalizować deficyt wynikający z krótkiego czasu skupienia się i wykorzystać ich potencjał.
\end{abstract}

Słowa kluczowe: skupianie się, pokolenie z, środowisko cyfrowe

1 (D) https://orcid.org/0000-0001-7793-4563. 
There are a few factors that have to be taken into consideration when discussing the $21^{\text {st }}$ century learners and the most effective ways to teach them. The question is actually not as simple as whether we should or shouldn't be using technology in the teaching process, or whether we like or detest the idea of the ever (or over) present screens and the internet. Or even if our perception is that 'students have never been as difficult as they are nowadays'. The key issue seems to be making an attempt to understand why present-day students behave the way they do and which factor affect their learning habits. The reality is as follows:

- the average attention span has dropped to 8 seconds, compared to 12 at the beginning of the millennium (Gausby, 2015, p. 6);

- Zees keep multitasking, especially when it comes to using screens;

- they stay connected at all times;

- the difference between the life in social media and in the real world is becoming blurred;

- and still - teachers task is to manage this reality and make students learn.

It is true - the $21^{\text {st }}$ century student is different than the one from the previous millennium. However, different should not be understood as worse. There seems to be common agreement that these changes have been caused by technology, some would even blame smartphones, social media or the Internet directly. The reality appears to be more complex, as the shape of the present day youth and their behaviours are the consequence of more long-term processes, our lifestyles in the technology centred world, as well as the changes dictated by economy. And as Twenge (2017, pp. 22-23) points out, these changes should not be referred to as positive or negative:

Given that many generational differences are positive or at least neutral, using words such as fault and blame doesn't really make sense. It's also counterproductive, leaving us squabbling about whom to blame rather than understanding the trends, both good and bad. Cultural change also has many causes, not just one - it's not just parents, but technology, media, business, and education working together to create an entire culture that is radically different from the one our parents and grandparents experienced. (Twenge, ibid.)

Prooday (2018), an occupational therapist and psychotherapist working with both parents and children, highlights the significance of parental influence on the child's development and the way young people function in the 
society, pointing out that it is scientifically proven that the brain has the capacity to rewire itself through the environment'. Mercer Dalton (2013) summarises the results of the study conducted byDr Gary Small at the Memory and Aging Research Centre, the University of California, Los Angeles (2008), concluding that 'after only five days of an hour-a-day use of Google, the newcomers' brain images were "rewired" to look like the brain images of the experienced users'. And this seems to be one of the most important areas of interest, as in the present-day world, 'the environment and parenting styles that we are providing to our children, are rewiring their brains in a wrong direction and contributing to their challenges in everyday life' (Prooday, 2018).

A complex characteristics of generations, beginning with the $19^{\text {th }}$ century Lost Generation, is presented by Graham (2019). Here, we are going to have a closer look at the generations that attend present day school and their parents, namely X, Y and Z, alfas, born after 2010, are still a bit of a question mark. As Manziaris (2014) presents an accurate caricature of the XYZ generations, quoting Don Tapscott, chief executive officer of Tapscott Group in Toronto:

My generation, [the boomers], grew up watching 24 hours of TV per week. We were the passive recipients of TV," Tapscott says. "[Gen Y] was the Net Generation, they came home from school and they would not turn on the TV, they would turn on their computer, reading, organizing, communicating. These kids you're writing about, they don't come home and turn anything on, because they are turned on all the time. (Manziaris, 2014)

Generation X children, as Graham (ibid.) indicates, born in 1960s and 1970s were 'growing up in a time of rampant divorce and an increase in the number of working mothers'. They were sometimes labelled "latchkey kids", as exposed to a lot of daycare, loneliness and boredom, and they were the ones of least nurtured by their parents. They were 'forced to become independent at young age' (Becker, 2015) and turned into young adults who appear to be 'cynical about the world, sceptical and pragmatic' (Seemiller and Grace, 2016). They have one of the lowest voting rates in all generation, and, according to Newsweek, drop out 'without even turning on the news or turning in to the social issues around them'.

Generation Y, or Millennials, born in the 1980 and up to 1994, grew up with the strong support of their Baby Boomers parents (Graham, 2019). They seem to have 'high expectations of their career, including pay, opportunities for advancement, fulfilling work and work-life balance (Seemiller and Grace, 
2016). As Seemiller and Grace continue, they are the first generation who grew up in a 'multimedia and interactive environment' and were surrounded by social media and internet $(2016$, p. 6). It is also worth noticing that as kids, they were 'often raised in dual income or single parent families [and] have been more involved in family purchases' (http://socialmarketing.org), which makes them more responsible and more marketing resistant adults.

And finally Generation Z, born 1995-2010. As these are the students that attend our schools at the moment, this group will be given more attention. Gen $\mathrm{Z}$ are parented mostly by Gen X, who, by contrast of them being the "latchkey kids", turned into the other extreme - the ever- and over-present parents, not only ready to be on right the spot react almost immediately, but actually "copiloting" their children's lives (Becker, 2015). As Graham (2019, pp. 22-23) continues, Gen Z feel relaxed about their parents' assistance, treating them more like friends than the older generation. Even at university, more than $50 \%$ of students stay in touch with their parents almost every day, mentally being teenagers when already in their twenties, and as she concludes, delay adulthood, 'taking on adult tasks at a much slower pace than their predecessor generations'. And even though social media allow constant connectivity, Gen Zers are considered to be the loneliest generation.

Gen $\mathrm{Z}$ are sometimes also addressed as 'Generation We' opposed to 'Me Culture' represented by earlier generations (White, 2018). As she continues, Gen Z, living in the interconnected world 'in the shadow of 9/11, growing up with global issues like climate change and poverty dominating the news' (ibid.), tend to be more actively involved. Their access to technology allows them to act even as teenagers, blogging, vlogging, and organizing fund-rising events.

Despite Gen Z's close relationship to their parents and social involvement, they are also referred to 'Gen Stressed', as although 'this generation's digital skills have many benefits (...) Gen Z's knowledge of the world's problems could outstrip their ability to change things' (White, 2018). Research conducted by the American Psychological Association (APA) highlights the poor condition of their mental health (Seymour, 2019), considering the fact that as many as $37 \%$ received 'help from a mental health professional' and 'only half said they felt they did enough to manage their stress'. As pointed out by Seymour (ibid.), prevailing symptoms of stress shown by Gen Z include 'feeling depressed or sad (58\%), lack of interest, motivation or energy (55\%) or feeling nervous or anxious (54\%)', and also 'lying awake at night due to stress (68\%).Graham (2019) accurately summarises Jacobson's analysis of how stress and anxiety impact students' learning abilities: 
This aspect of Gen Z's peer personality seems particularly challenging for educators, because anxiety and stress have so many negative correlations with learning. They stretch our attention span, affect our perception, skew our filtering process toward negative and fear inducing stimuli, weaken our memory, and obstruct our high-level cognition. They also steal our sleep, which negatively impacts our attention and learning. (Graham, 2019, p. 20)

Nief and McBride's (2017) Mindset List includes 60 features of people born in 1995, saying that for example they are 'the sharing generation, having shown tendencies to share everything, including possessions, no matter how personal'. For their online activity, 'PayPal has replaced a pen pal as a best friend on line', 'a tablet is no longer something you take in the morning', 'they could always get rid of their outdated toys on eBay' and 'have always been able to plug into USB ports. For their social routine, 'having a chat has seldom involved talking, they don't need 'to go to their friend's house so they could study together', 'with GPS, they have never needed directions to get someplace, just an address' and 'they have never attended a concert in a smoke-filled arena'.

One of the concerns seems to be the attention span that young people nowadays (don't) have nowadays. They constantly multitask and switch between multiple screens, and between their real and online lives. We worry about young people not paying attention to the things they study. Some researches seem more threatened by the trends than others. Savitt (2010) alarms that Gen $\mathrm{Z}$ have developed Acquired Attention Deficit Disorder (AADD), which she explains as 'chronic mass distraction triggered by constant immersion in multiple media platforms simultaneously (texting while Facebooking while YouTubing while eating while studying, for example)' (Fuenres, 2014, p. 676).

Gen $\mathrm{Z}$ is able to access and process information on their mobile devices relatively quickly and efficiently, however Fuenres (ibid.) points out that 'AADD handicaps their ability to process small bits slowly and critically', summarising disgracefully that 'digital speed supplants cognitive slowness'. This perspective is also supported by the neuroscientific research conducted at the University of California (Small, 2008), which explains how online activity and extensive use of technology affect areas responsible for memory in young people's brains:

Many neuroscientists believe that the constant exposure to high levels of technology is altering the neural connections and stunting frontal lobe 
development in younger generations. The frontal lobe is the higher order reasoning center of the brain, where working memory is located. For example, studies show that excessive computer gaming leads to suppressed functions in the frontal lobes in favour of stimulating lower order brain centers controlling movement and vision. Additionally, it shows a decrease in working memory. (Dalton, 2013, p. 419)

And looking at how some of our students behave in the classroom, these facts are hard to question. However, some researchers take a more positive perspective and claim that because of our brain plasticity, the weakness indicated by researchers can become an opportunity for development in other areas. According to the Microsoft Canada study (2015), which focuses on how attention spans affect the marketing strategies for the present-day, digital, multitasking and multi-screening consumers,

overall, digital lifestyles deplete the ability to remain focused on a single task, particularly in non-digital environments. But, all is not lost. Connected consumers are becoming better at doing more with less via shorter bursts of high attention and more efficient encoding. (Gausby, 2015, p. 4).

The study by Microsoft (2015, p. 9) points out to the different types of attention, beginning with sustained attention, which means 'maintaining prolonged focus during repetitive activities', followed by selective attention, which addresses 'maintaining response in the face of distracting or competing stimuli', and finally alternating attention, which refers to 'shifting attention between tasks demanding different cognitive skills'. Jacobson (2010, p. 421) defines attention as 'the ability to attend to desired or necessary stimuli and to exclude unwanted unnecessary stimuli', highlighting the fact that attention is not just about attending and processing stimuli, but actually about ignoring the unwanted ones. He also continues it is needed not just for the process of absorbing, but also 'processing, remembering and retrieving information', thus making connection between working and long-term memory processes. According to Jacobson (ibid.),

The learner must not only consciously attend to the task to be done, but must also exercise cognitive control of any interruptions and distractions from that task. Only thosetasks attended to will be remembered, so if interruptions and distractions are not controlled, the right things may not be remembered. This is because of the limits of working memory or the limits of attention when 
using working memory, depending on the study or the theorist. (Jacobson, 2010, p. 423)

And unfortunately for Gen Z, according to Microsoft Canada's report, 'heavy multi-screeners find it difficult to filter out irrelevant stimuli - they're more distracted by multiple streams of media'. Their 'long term focus erodes, with increased digital consumption, social media usage and tech savviness' (see Figure 1\&2) (Microsoft Canada, 2015, p. 18). Concluding, the learner's cognitive ability to remember and later on retrieve the remembered information is the outcome of their ability to control and not pay attention to distractions. This indicates that for Gen Z, with their ability to ignore distractions at the lowest level, the process of learning requires more effort compared to other generations.

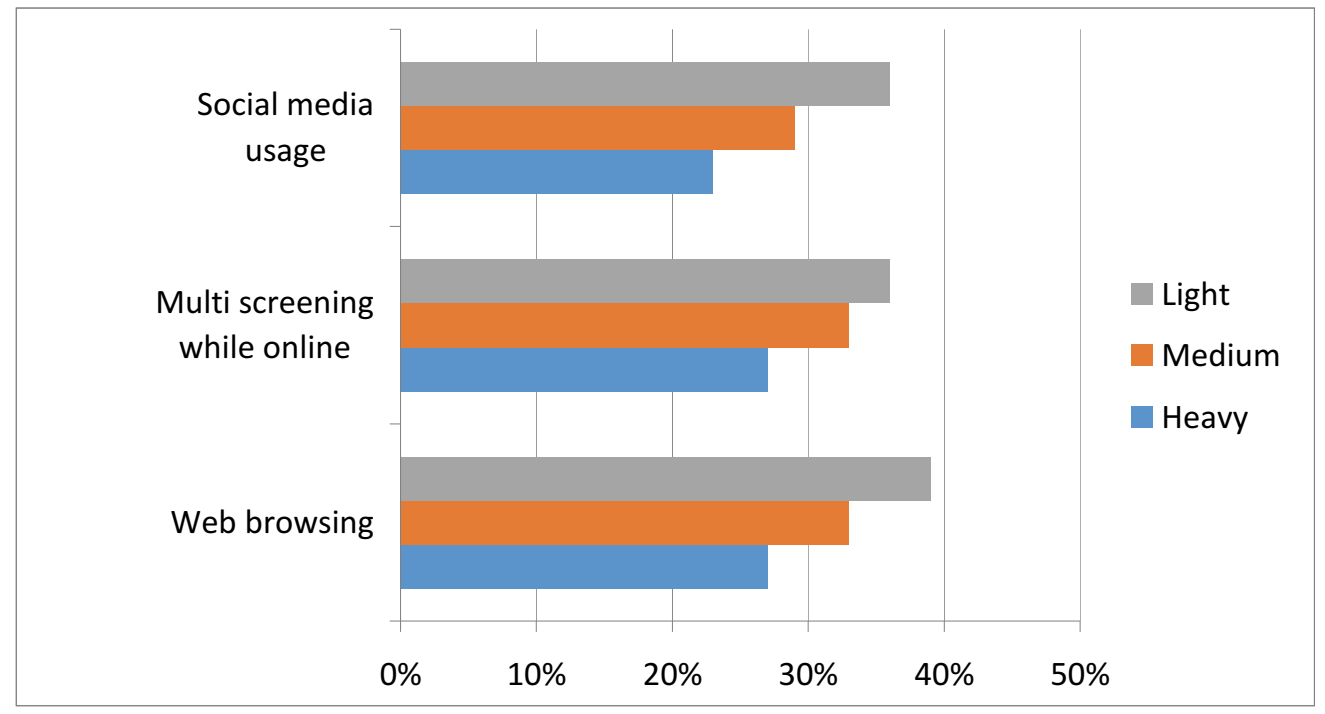

Figure 1. Percentage of high sustained attention by behaviour (Source: Microsoft Canada Report, 2015, p. 18)

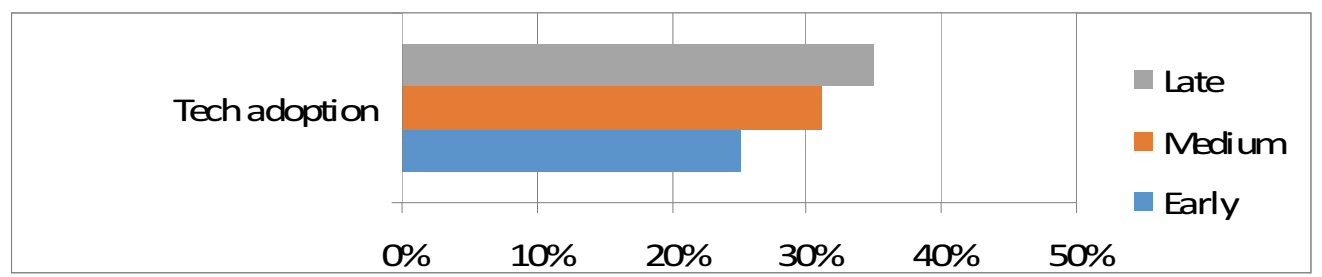

Figure 2. Percentage of high sustained attention by the age of tech adoption (Source: Microsoft Canada Report, 2015, p. 18) 
Some researchers are not totally pessimistic about Gen Z and see their potential. Zees are not only complete digital natives, born to the world of computers, the Internet and social media, but they also the ones who can outperform older generations in some areas. Their intuitive functioning in the digital space is not the only asset, despite their depressive tendencies, short attention span and ability to become distracted definitely stronger than the ability to get focused.

In Microsoft Canada's report (2015) the ability to concentrate, connect and encode are studies in two groups of respondents, group one consisting of light / no social media user and group two of moderate and heavy ones. The results show that heavier social media users pay more attention in interactive (digital) environments, but their attention scores are lower than lighter users in more passive experiences (TV)'. This shows the adaptive qualities of our brains. The research also proves that in both environments, their bursts of attention allow heavier users of social media to process information and encode it to memory more efficiently' (see Figure 3\& 4) (2015, p. 20).The level of attentions is similarly affected by the age when we start using technology. Not surprisingly, moderate and heavy social media users and early tech adopters outperform their less savvy friends in the interactive environments.

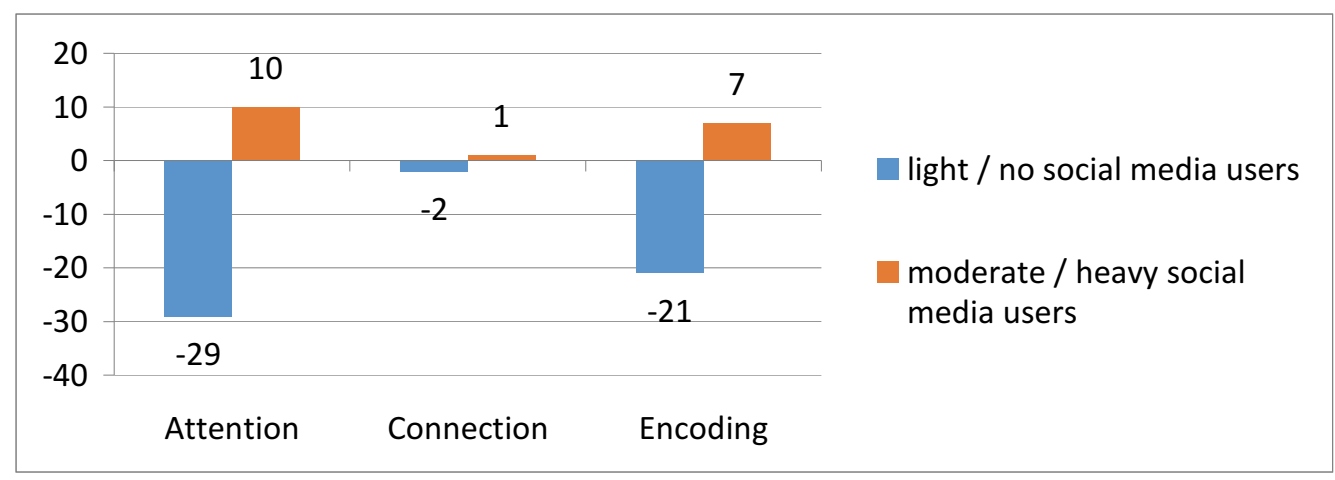

Figure 3. Overall performance across attention in interactive environments (Source: Microsoft Canada Report, 2015, p. 21) 


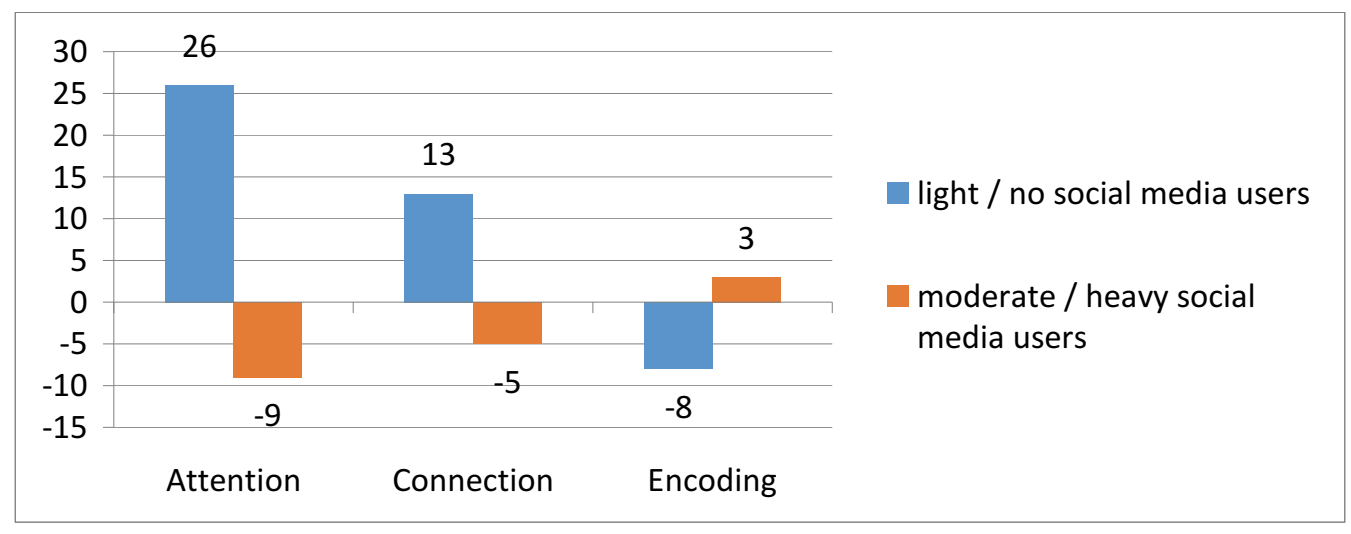

Figure 4. Overall performance across attention - TV only

(Source: Microsoft Canada Report, 2015, p. 21)

The report indicates that the bursts if attention are significantly more frequent with people who use technology and digital screens a lot than in case of those who don't use them too often (Figure 5), similarly to early tech adopters (Figure 6). The burst of attention is understood as and with more frequent bursts of attention, they can process information quicker and more effectively. They need less time to decide if they are attracted to a piece of information or not, and because of that they are able to process efficiently bigger amounts of information that other people who are not that tech savvy. The Microsoft Canada's research concludes that both heavy social media users and early tech adopters 'have lower sustained attention in the long run but more bursts of high attention in the short term' (2015, p. 22).

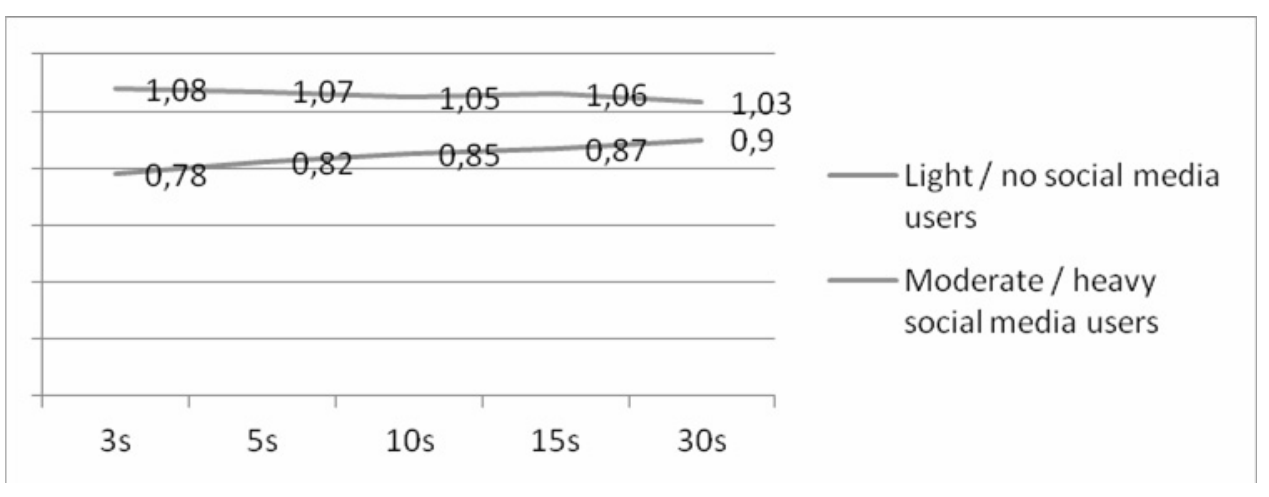

Figure 5. Average number of peaks in attentional behaviour by timeframe according to social media usage (Source: Microsoft Canada Report, 2015, p. 20) 


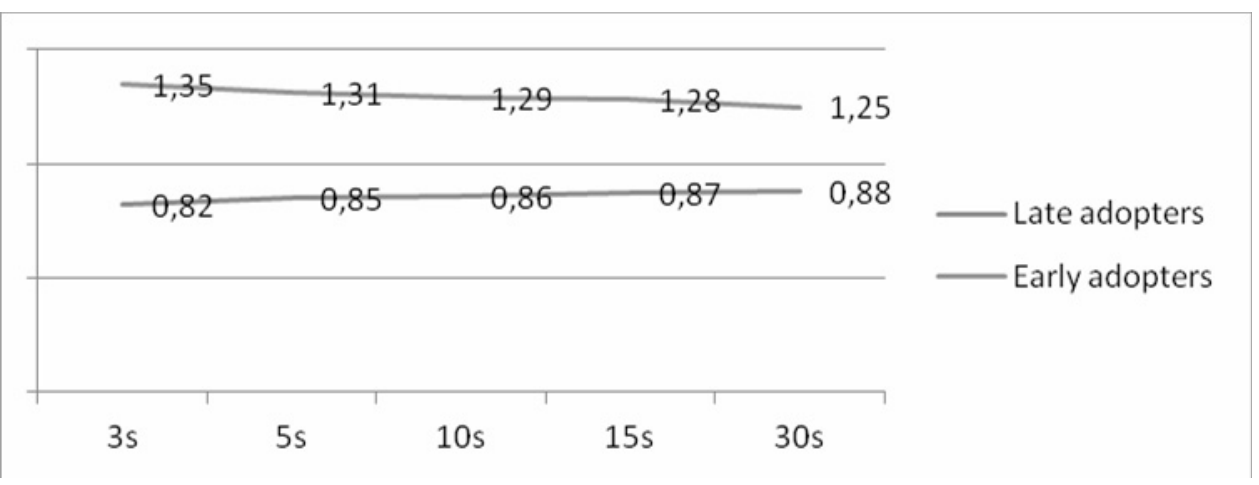

Figure 6. Average number of peaks in attentional behaviour by timeframe according to the age (Source: Microsoft Canada Report, 2015, p. 22)

One of the most interesting points highlighted in Microsoft Canada's Report is the fact that 'an active social media lifestyle builds alternating attention - to a certain point (2015, p. 40) (Figure 7). According to the research, multi-screening improves the connecting and encoding abilities. As the numbers show, moderate social media users are also better at 'simultaneously processing information from different sources' (ibid., p. 43) than people who do not use social media. However, this ability decreases significantly with heave social media users, whose alternating attention is at the levels much below all two other groups.

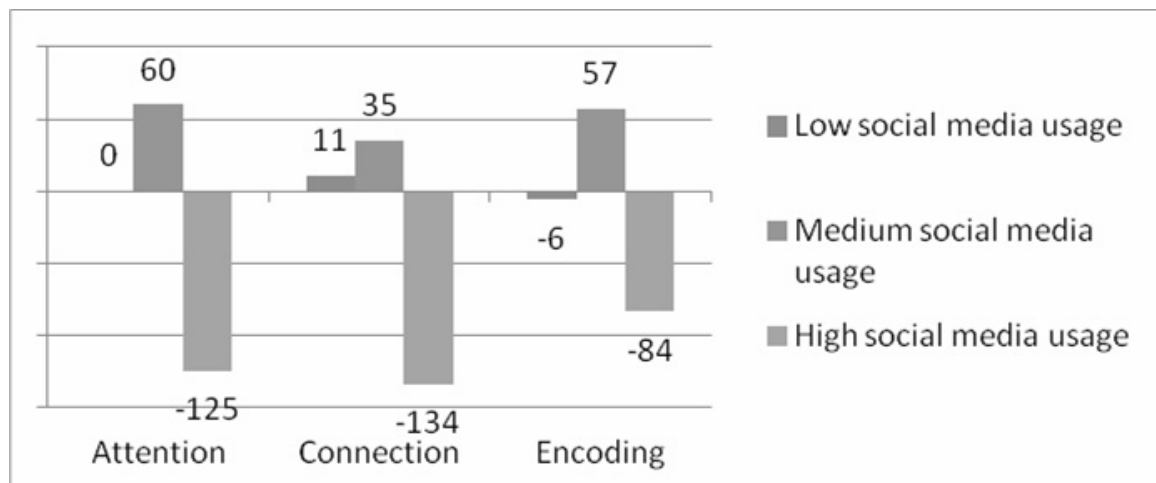

Figure 7. Overall performance across attention, connection and encoding by social media usage (Source: Microsoft Canada Report, 2015, p. 40)

Looking at Microsoft's data, two questions arise: what is the border line between the moderate and heavy users, and how to make them not exceed 
the invisible border between taking the advantage and falling into the trap of social media.

From the perspective of teaching Gen Z students, the key issue seems to be the challenge not only to attract their attentions or keep them focused, but rather how to create situations that will result in the bursts of attention, and how to deepen the learning experience, so that it can become more recognizable for their brains in the long term run than other tasks performed simultaneously.

First of all, it is necessary to come to an agreement with the facts. Digital environment is the natural one for students, they are multitaskers, they are multiscreeners, and the fact that they are doing something with one of their screens does not automatically mean they are not listening.

The educators' attitudes on how to handle Gen $\mathrm{Z}$ in the classroom vary significantly. Some are for using technology in the classroom on everyday basis and involving their screen activity into the learning process (Affleck, 2013, Zlatkov, 2019). Other suggest that the application of screens and mobile devices in class should be limited, sometimes even creating zones that are free of technology (Howe, 2019, Dalton, 2013, Carr, 2010). Whenever you go for the extreme, there is always some risk.

Microsoft Canada's Report suggest three ways to attract customers from the marketing point of view: Be different, Get moving, Draw consumers in (2015, pp. 34-35). These strategies could work equally successfully in the language classroom.

Point One - Be different. With so many various stimuli from the screens and the world around, our students must find something that will attract them to our lesson. If the teacher is unable to create situations resulting in more frequent bursts of attention, most students' attention will be attracted by other stimuli. And it is not enough to just ask students to concentrate. They will, but just for the short period their attention span lasts (8 seconds). A language lesson can begin in a little surprising way. Doing the course book should not be the only activity, and the routine that is necessary in the teaching process should be supplemented with something out of ordinary.

Point Two - Get moving. As we want to keep regaining students' attention, the teaching process must be well paced, definitely more active than passive. It the teacher can create language learning situations that involve learning by doing, not just looking, students can become and remain more actively involved. And they can be performing activities both within and outside the digital environment. Doing exercises in a passive way seldom 
involves students' active participation, but if the teacher turns the same exercise into a game or a more interactive activity, they will be in.

Point Three - Draw the in. Gen Z want to take responsibility for their learning, preferring a more independent and a more self-directed approach (Zlatkov, 2019), they are conscious about what they want to and don't want to learn. If they are involved in the decision making process, they will feel more motivated to participate in the classes. Also, considering the almost unlimited access to information and online resources, students can become involved not just in the learning, but also the teaching process. Taking advantage of their digital abilities, they can find and present interesting materials in class, they can be involved in creating language tasks and activities, especially online one, for other students.

And finally considering their emotional imbalance, depressive tendencies and the expectations of instant results, it is of key importance to maintain positive atmosphere, express expectations of success and offer praise. As Jurenka et al. claim, 'the most effective way, how to keep and manage the existing good working relationship with the generation $\mathrm{Z}$ is to transparently reward them on their real performance' (2018, p. 251). The reward will keep them more positive, more involved and because of that, more focused.

Summarising, Generation $\mathrm{Z}$ are not an easy generation to handle, and there is no one recipe how to deal with them. If we want to succeed in teaching them, or actually making them learn, we should make an attempt to understand them, the reality they are growing up in, which is so different from the reality many of us remember as our childhood or teenage years. And for Zees, the reality in which they are growing up is not their choice, it is the given.

\section{Bibliography}

Affleck, C. (2013, June 11) Today's youth: The rewired generation. Retrieved 2020, January 4 from https://www.bizcommunity.com

Becker, M.A. (2015). Understanding the Tethered Generation: Net Gens Come to Law School, 53 DUQ. L. REV. 9, 14.

Carr, N. (2010), The Shallows: What the Internet Is Doing to our Brains. New York: W.W. Norton and Company Ltd.

Dalton, K.M. (2013). Their Brains on Google: How Digital Technologies Are Altering the Millennial Generation's Brain and Impacting Legal Education, 16. SMU Science and Technology Law Review, 409. Retrieved 2019, December 20 from https://scholar.smu.edu/scitech/vol16/iss3/2. 
Fuenres, G. (2014). Pedagogy With and Against the Flow: Generational Shifts, Social Media, and the Gen $Z$ Brain. In J. Stuart \& M. Wilson (Eds.), 102nd ACSA annual meeting proceedings, globalizing architecture/flows and disruptions (pp. 669-677). Miami Beach, FL: Association of Collegiate Schools of Architecture. Retrieved 2019, December 20 from https:/www.acsa-arch.org/proceedings/ Annual\%20Meeting\%20Proceedings/ACSA.AM.102/ACSA.AM.102.76.pdf

Generations X, Y, Z and the Others (n.d.). Retrieved December 30, 2019 from http://socialmarketing.org/archives/generations-xy-z-and-the-others.

Harris, J. (2010, August 19) How the Internet is Altering Your Mind, GUARDIAN. Retrieved 2020, January 4, from http://www.guardian.co.uk/technology/ 2010/aug/20/internet-alteringyour-mind.

Howe, N. (2010). Meet Mr. and Mrs. Gen X: A New Parent Generation. AASA - The School Superintendents Association. Retrieved December 19, 2019 from https://www.aasa.org/SchoolAdministratorArticle.aspx?id=11122.

Jacobson, S.M.H. (2010). Paying Attention or Fatally Distracted? Concentration, Memory and Multi-Tasking in a Multi-Media World, Journal of Legal Writing Institute, 16, 419-462. Retrieved 2020, January 3 from https://papers.ssrn.com/ sol3/papers.cfm?abstract_id $=1641768$.

Jurenka, R., Starecek, A., Vranakova, N. \& Caganova. D. (2018, November). The Learning Styles of the Generation Group $Z$ and Their Influence on Learning Results in the Learning Process. ICETA 2018, 16th IEEE International Conference on Emerging eLearning Technologies and Applications. Retrieved 2020, January 3 from https://www.researchgate.net/publication/ 329648919_The_Learning_Styles_of_the_Generation_Group_Z_and_Their_Infl uence_on_Learning_Results_in_the_Learning_Process

Manziaris, L. (2014, September 25). Generation Z: The kids who'll save the world? The Globe \& Mail. Retrieved, 2020, January 3 from https:/www.theglobeandmail. com/life/giving/generation-z-the-kids-wholl-save-the-world/article20790237/.

McSpadden, K. (2015, May 14). You Now Have a Shorter Attention Span Than a Goldfish, Time. Retrieved December 01, 2019 from https://time.com/ 3858309/attention-spans-goldfish/.

Nief, R. \& McBride, T. (2017). The Mindset List for the Class of 2017, MINDSET LISTS. Retrieved 2020, January 6 from http://themindsetlist.com/lists/beloit-collegemindset-list-class-2017/.

Prooday, V. (2019, May 24) The silent tragedy affecting today's children. Retrieved December 21, 2019 from https://yourot.com/parenting-club/2017/5/24/what-arewe-doing-to-our-children.

Savitt, K. (2010). Gen Z: The Age of the Curator, lecture presented at the Web 2.0 Summit on November 17th, 2010. Accessed 2020, January 4 from www.youtube.com/watch?v=ZfqF1r7LBCA.

Seemiller, C. \& Grace, M. (2016). Generation $Z$ Goes to College. San Francisco: Jossey Bass. 
Seymour, E. (2019, August 25). Gen Z: Studies Show Higher Rates of Depression. Retrieved 2020, January 6 from https://www.apa.org/pubs/journals/releases/abnabn0000410.pdf

Small, G. \& Vorgan, G. (2008). iBrain: Surviving the Technological Alteration of the Modern Mind. Harper.

Twenge, J.M. (2017). Why Today's Super-Connected Kids Are Growing up Less Rebellious, More Tolerant, Less Happy - and Completely Unprepared for Adulthood. Simon and Schuster.

White, S. (2018, May 12). Generation Z: The Kids Who'll Save the World? The Globe \& Mail. Retrieved 2019, December 19 from https:/www.theglobeandmail.com/ life/giving/generation-z-the-kids-wholl-save-theworld/article20790237/.

Zlatkov, B. (2019, February 14). 7 Surprising Insights About How Gen $Z$ Wants to Learn. Retrieved 2020, January 3 from https://learning.linkedin.com/blog/ learning-thought-leadership/do-you-know-how-gen-z-really-wants-to-learn--7surprising-insigh 